\title{
VEEL KORD MULKIDE RUMALUSEST
}

\author{
KERSTI LUST, TAAVI PAE, EVAR SAAR
}

$\mathrm{A}$ jakirja 2017. aasta juuninumbris avaldatud artiklile (Pae, Lust 2017) mulkide rahvanimetuse saamisloost reageeris juulis vastulausega keeleteadlane Lembit Vaba (2017). Mõistagi on hea, et mulgi nimetuse päritolu käsitlev artikkel tekitas vastukaja, sest eeskätt diskussioonist saab areneda uus teadmine.

Vaba osutab oma artikli algul indoeuroopa keeli käsitlevatele töödele, kus viidatakse ka Venemaalt pärit saksa juurtega slavistile Max Vasmerile, kes tõi teaduskirjandusse väite, et mulgi nimetus on laen läti keelest (Vaba 2017: 534). Vasmer tõdeb, et sõna $m u l ' k$ esineb läänemeresoome keeltest ainult eesti ja liivi keeles, neiski harva, ning järeldab, et seega on see sõna võõrpäritolu. Läti keeles on aga sõna mul,kis väga vana. Vasmer jätkab: „Nii siis tuleb siin tunnistada laenu läti keelest liivi ja eesti keele. On ainult küsitav, kuidas sai võimalikuks üht rahvahõimu nimetada sõnaga, mis 'lollpead' tähendab. Siin esinevad muidugi mitmed seletusvõimalused. Kõige tõenäolisem paistab mulle järgmine: Õige sagedasti nimetatakse rahvaid ja hõime nende kõnemoodu iseäralduste järele" ning toob selle kohta näiteid slaavi keeleruumist (Vasmer 1920: 344). Edasi arvab ta, et küllap mulgid ise seda sõna kasutasid (allikatest pole siiani kinnitust leitud - autorid) ja kuna see teistele tundmata oli, siis võtsid nad selle nende kohta tarvitusele. Ja võtab kokku: „Olgu mis põhjusel ka sõna mulk hõimunimeks ei saanud, igatahes võin ma veel sarnase tunnistuse ühelt teiselt keelealalt ette tuua, kus 'lollpead' tähendav sõna hõimunimeks on saanud" (Vasmer 1920: 345). Näite toob ta Balkanilt.

Vasmeri artikkel põhineb Emakeele Seltsis (ES) 8. mail 1920. aastal peetud ettekandel (ESA 1921: 8-9). Sellel koosolekul oli lisaks Vasmerile ettekandjaks ka Lauri Kettunen, kes samuti arvas, et sõna mul'k pärinemises läti keelest poleks midagi iseäralikku. Arvukate sõnavõtjate mõttearendused olid mitmesuunalised, kuid valdavalt otsiti seoseid läti keelega. Albert Saaberk (Andrus Saareste) teatas kategooriliselt, et läti päritolu on kindel, ja arutelu lõpetas Johannes Aavik oletusega, et rahvanimetus pärineb Lätist saabunud sisserändajatelt.

Mikroetnonüümi mulk päritolu uurima asudes pidasime selle läti päritolu mitte kindlaks, vaid pigem kaheldavaks. Esmalt otsisime vastust küsimusele, kus ja millal see nimetus kirjalikes allikates kasutusele võeti ning kuidas on nimetuse saamislugu seletatud. Nimetus ilmub eesti kirjakeelde 1860. aastatel kirjatükkides, mis käsitlevad viljandimaalaste talude ostu Tartumaal, ning mulk on see, kes ostab ära tartumaalase talu. „Sissetungijaid” sõimati mulkideks. Viljandimaalt Tartumaale tulnud paremal järjel sisserändajate mulkideks nimetamist kohalike poolt märkasid ka baltisakslased (Körber 1866). Tollast ilukirjandust, ajakirjanduslikku poleemikat, mälestusi, asustusloolisi ja rändega seotud allikaid kompleksselt vaadeldes leiab rohkelt pidet teooriale, et mulgi rahvanimetus pärineb talude nimest ning levis seoses talude päriseksostmisega. Uurimuse lähenemisviis oli kontekstikeskne ja sotsiaal- 
ajalooline: mulkide kohta teada olevat pärimust ja mälestusi suhestati sotsiaalajaloolise keskkonnaga ning sõna kasutuselevõttu ja algset levikut vaadeldi konkreetses ajaloolis-kultuurilises situatsioonis. Vaba heidab uurimuse autoritele õigustatult ette keeleajaloo vähest tundmist; siinkohal peab aga omakorda nentima, et Vaba väldib kõiki kultuuri- ja sotsiaalajaloolisi aspekte. Samuti kipub ta andmetest välja noppima seda, mis toetab soovitavat tulemust, ning välja jätma muud (või selle tähtsust vähendama). Nii ongi Vaba keskendunud lätikeelse sõna etümoloogiale, otsides pingsalt võimalusi kinnitamaks lätilaenulisuse teooriat.

Oleme ühel meelel nende keeleteadlastega, kelle meelest sõna mulk etnonüümi tähenduses on noor, kuid ei arva, et see on läti päritolu. Esimeses uurimuses ei leitud allikatest tõendeid kinnitamaks Vasmeri jt mõttearendusi, et rahvanimetus oleks läti keelest üle võetud. On küll võimalik, et pilkenimi sündis sajandeid tagasi ja sellest pole mingeid märke, kuid samas on mitu teema käsitlejat toonitanud, et mikroetnonüümi mulk tekkeaeg jääb XIX sajandi keskpaika (vt ka ESA 1921: 9). Vaba märgib, et aniharva õnnestub seista uue sõna imelise sünnihetke juures (Vaba 2017: 535), kuid antud juhtumi puhul arvab hulk ilu-, aja- ja mälestuskirjanduse autoreid end kirjeldavat selle sündi nii ajas kui ka ruumis sündmuse lähedal viibinutena. Eesti murdesõnastikud ei tunne mulki tähenduses 'loll'. ${ }^{1}$ Läti rahvaluule väljaanded ei kinnita sõna mul,kis kasutamist eestlaste kohta (Pae, Lust 2017: 440). Eestlasi on iseloomustatud sõnaga melni ('mustad') mulkide mustade kuubede järgi (Rozenbergs 2005: 184jj). ${ }^{2}$ Folkloorsete etnonüümide levik on äärmiselt kohalik, nagu Vaba (2017: 536) rõhutab, kuid seni pole läti vanemast folkloorist mulkide kohta säherduse nime kasutamisest kõnelevat materjali leitud ja pelgast oletusest, et see võinuks olemas olla, jääb väheks. Küll aga on teooriat nimetuse mulk läti päritolust väga jõuliselt viidud lõunanaabrite kaasaegsesse teadmisse (nt Odita Krenberga ja Gunta Sloga dokumentaalfilm „Toomas mulkide maalt” (2016)).

Uurimistulemused kinnitavad, et emotsioonidest juhinduvad nöökiva või koguni halvustava sisuga mikroetnonüümid pole tavatud ja need on kahtluseta eksoetnonüümid (Vaba 2017: 535). Ka meie väitsime, et nimetus mulk on eksoetnonüüm ja omas algselt halvustavat tähendust, olles suisa sõimusõna, kuid kultuuriajaloolised dokumendid lubavad arvata, et nimetuse andsid tartumaalased, mitte lätlased. Sõimunime tuletamine koha- resp. talunimest võib olla haruldane, kuid sedavõrd just huvitav ja omanäoline.

Kui peab paika teooria, mis tuletab mulkide päritolu Mulgi-nimelistest taludest, pole veel lahendatud küsimus Mulgi talu nimest. Artiklis „Mulkide nime saamisloost..." ei välistatud, et Abja mõisa Atika küla aladele jäänud Mulgi talude nimi, kust nn algmulgid Tartumaale tulid, võib pärineda läti keelest. Ent kahtlusi äratab asjaolu, et Mulgi lisa- ja hiljem talunime leidus ka mitmel pool mujal Eestis (vt joonist) - just Mulgi- ja mitte Mulgu-nimelisi,

${ }^{1}$ Mulk : mulgi seostub peale rahvanimetuse veel mõne täiesti teistsuguse tähendusega. Muhus on mul'k olnud ka käbi, Kihelkonnal muuluka ja Kodaveres linapeo tähenduses. Kihelkonnal on $m o l ' k$ või $m u l ' k$ lisaks laulu meloodiat tähendav sõna. (EMS) Vaba eksib Pae ja Lusti lause mõtte esitamisel: me ei väida, et tähendust 'loll' ei tunne murdekeel, vaid eesti murdesõnastikud, ja nii see ka on. Jämajas on küll Vaba väitel registreeritud selline kasutus (Vaba 2017: 535), kuid see fakt pole seotud mikroetnonüümi mulk sünniga.

${ }^{2}$ Tegemist ei ole küll kohaliku, vaid üle Läti tuntud väljendiga (laul LD 2851, kokku 23 varianti; esimene ülestähendus P. Lapsin̨ši poolt Ruhjas: LD). 


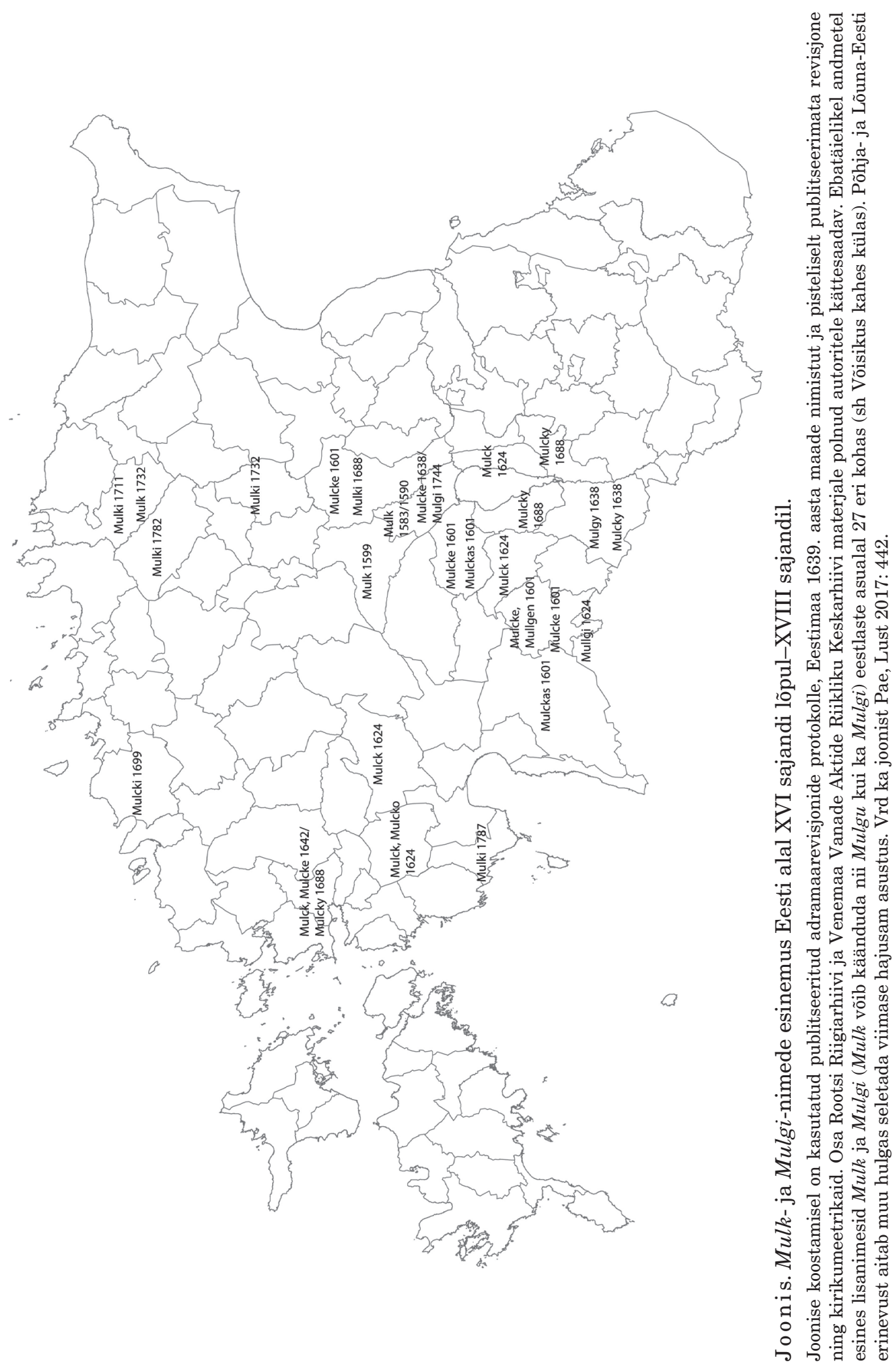


nagu Vaba (2017: 537) arvab tolle loo autoreid väitvat. Sedastati, et Mulgi nime etümoloogiline päritolu jääb ebaselgeks ja eesti-läti keelekontakti alal (nt Kariste mõisas oli võõrapäraseid lisa- ja talunimesid) on läti algupära võimalik, kuid osutati ka teistele võimalustele: see on olnud soomlase lisanimi ja võib olla seotud sõnaga mullik(as) (Pae, Lust 2017: 440-443). Seekord peatume neil võimalustel pikemalt, tuginedes Eesti rahvastiku- ja asustusajaloo allikatele. Kui siiani on Mulgi lisa- ja talunime uurijate tähelepanu olnud koondunud üksiti Eesti-Läti piirialadele või ka Läti alale tervikuna, siis käesolevas artiklis vaatleme lisa- ja talunime Mulk ja Mulgi levikut kogu eestlaste asualal.

Atika küla Mulgi lisa- ja talunime päritolu ei pea me sugugi lahendatuks ka selle käsitlusega, kuid loodame astuda veel sammukese lähemale teadaolevate faktidega võimalikult kooskõlas olevale versioonile Mulgi-nimede ja seeläbi ka rahvanimetuse päritolust.

\section{Lisa- ja talunimed Mulk ja Mulgi}

Varasemad asustus- ja rahvastikuloo ning ka majandusdokumendid (nt Tallinna arve- ja kaubaraamatud, maksunimistud) on olnud uurijate huviväljas pikka aega ja neist üksikuid on ka publitseeritud (nt Vanem Tallinna Jaani... 1925; Stackelberg 1928; Johansen 1938; Tallinna turberaamat 1939; Vogelsang 1976). Sellest väga fragmentaarsest ja põhiliselt Põhja-Eesti (sh Tallinna) kohta käivast ainesest on varasemad uurijad leidnud Michell Mulk'i 1455. aastal Tallinnast (Vogelsang 1976), ${ }^{3}$ Mulck'i 1564. aastal Järvamaalt (Palli 1961a: 135; Vaba 1997: 136) ja 1591. aastal Tallinnas turvet saanud lihunik Mulck Toennis'e, kes oli ohtlikult haavanud talupoeg Ivo Lulli Keskkülas (Kir) (Tallinna turberaamat 1939: 287). Enamasti on turbeandmine tähendanud, et kusagil linnast väljas toime pandud kuriteo sooritaja põgenes linna kaitse alla. Turberaamatus on kohati nimetatud enne talupoja lisanimi, ilmselt oli tegu talupojaga, kes võis pärineda Keskkülast. 1688. aastal elas Keskkülas neli peremeest lisanimega Mulcky (Tönniss, Jahn, Mart ja Jürgen), üks Mulcka ja neli Mullika (RA, EAA.1.2.941, 1523 jj). ${ }^{4}$ Lisa- ja talunimi Mulgi esineb siin edaspidi eri allikate järgi järgmisel kujul: 1726 Mulgi 1732 Mullgi 1766 Mulgi 1782 Mulky 1794 Mulgi (RA, EAA.3.1.459, 1 147p; EAA.1242.1.1, 1 3, 126p; EAA.1864.2.IV-8, 1 366p). Tegemist oli hajataludega. ${ }^{5}$

Mulgy/Mulki lisanime on Eesti asukatest kandnud isik, keda allikates tähistatakse etnonüümiga „soomlane”. 1638. aasta maarevisjoni järgi asus „sel aastal” Roobe mõisa (Hel) soomlane Mulgy Thomas, kel oli poeg Oluf (Rev. 1638: 131; Pae, Lust 2017: 440). Soome päritolu võib oletada ka 1688. aastal Vana-Põltsamaa mõisa all kirja pandud Mulki Jaagu puhul, kes „vana soldatina" kasutas mõisast saadud maad (RA, EAA.308.6.299, 1 2). 1744. aastaks oli 1/8-adramaaline Mulcki Jaagu koht mõisastatud ja samal ajal on Vitsjärve küla all kirjas pisike Mulcki Hansu majapidamine (1811 Mulgi) (RGADA.274.1.210/1:28, 39; RA, EAA.1865.3.236/10, 132 ).

${ }^{3}$ 1459. aasta rae trahvihärrade raamatus märgitakse, et ta ei ole kodanik (TLA.230.1.Aa 4a, 1 53r). Vt ka Saareste 1935: 139.

${ }^{4}$ 1642. aastal kujul Mulcke, Mulck, Mulke (LVVA.7349.1.217, $1299 p, 325$ ).

${ }^{5}$ RA, EAA.1.2.C-IV-208 Mulck'i talud. Vt ka EAA.3.1.468. http://www.ra.ee/apps/ adramaad/ (30. IX 2017). 
XVI-XVIII sajandi maarevisjonide protokollidest pole Eesti alalt seni tuvastatud Mulck/Mulcke / Mulki/Mulgi lisanimega isikuid, kelle puhul võiks allikast nähtuda läti päritolu. ${ }^{6}$

Sõnale mulkisis viitab 1601. aastal Lätis Pinte jõest ja Burtnieki järvest lõunas üles tähendatud lisanimi Multiss (Švābe 1933: 560). ${ }^{7}$ 1638. aasta revisjonis on Rūjiena (Ruhja) mõisale kuulunud ja 1560. aastal Vene vägede poolt põletatud Pleckumi küla alla märgitud viie aasta eest tulnud kuramaalane Mulggi Thomas, kel on seitsmeaastane poeg (Vidzemes... 1638, 3: 730). ${ }^{8}$ Rohkem Liivimaa Läti osas (Vidzeme) 1638. aasta revisjonis sellise lisanimega talumehi kirjas pole. 1601. aastal on Pleckumi vakuses kirjas Mullgens (Švābe 1933: 570) ja pole selge, kas Thomas tuli Kuramaalt koos lisanimega Mulggi või hakati teda nii hüüdma uues kohas talu nime järgi. ${ }^{9} 1681$. aasta revisjonist leiame Mulge lisanime taas vaid samast paigast (Dunsdorfs 1974: 103). Jānis Endzelīns mainib „vanadest allikatest” pärit teadet mulcke talust Rūjienas (Endzelīns 1961: 456-457; Vaba 2017: 537), kuid allikat ei õnnestunud meil tuvastada. $^{10}$

XVII sajandil esines meid huvitavat lisanime Liivimaa Eesti osas mitmel pool (vt joonist). ${ }^{11}$ Tänase Mulgimaa aladel leidus seda Karistes (Võibre k Mulcke Rautzep 1601), ${ }^{12}$ Helmes (Mulcky Jack 1638), Paysto külas (Mulggi Hann 1638), Veeliksel (Mulggi Hann 1638) ja Abjas (Atika k Mulcke Jaack, Mullgen Peter 1601) (Rev. 1638: 69, 79, 123, 131; Rev. 1601: 146, 152). Atikal esineb nimi hiljem kujul Mulcke (1675), Mulcken (1689), Mulcki (1698) (RA, EAA.1.2.460, 1 300; EAA.1862.1.383; EAA.1275.2.1, 159 ).

XVII sajandi esimeste kümnendite Põhja-Eesti kohta samaväärsed publitseeritud allikad puuduvad. 1638. aastal toimus revisjon õigupoolest ainult Liivimaal, sest Eestimaal piirdus asi sellega, et mõisaomanike või -valitsejate poolt kubermanguvalitsusele esitatud aruannetest koostati Eestimaa mõisamaade nimistu, mis sisaldab teateid ainult u 170 mõisa kohta.

Paul Johanseni kirjatükis, mille nappi kasutamist Vaba pahaks paneb, markeerib autor XVII sajandi esimeste kümnendite maarevisjonidele toetudes paari lausega Ruhja kihelkonna lätistumise kulgu (Johansen 1938: 52;

${ }^{6}$ Autorid ei saanud kasutada Rootsi Riigiarhiivis Läänemereprovintside maarevisjonide kogus asuvaid, lünklikult säilinud Liivimaa 1638. aasta revisjoni inkvisitsiooniprotokolle, kus uustulnukate päritolu märkimisel ollakse täpsemad (Vasar 1931: 553, 556).

${ }^{7}$ Lisanimi Molck esineb ka Skujenes (Švābe 1933: 458). Multiss sarnaneb Viljandimaalt XVI sajandil kirja pandud nimega Mutli Multi, mis praegu elab edasi perekonnanimena Mutli Mutle. Lisanimed Molth, Multh võivad viidata ka läti verbi kujule *mult 'jahvatama'. Sõna mulkis pärineb samast tüvest: malt > maldīties > mulst > mulkis (Karulis 2001: 607). Siin ja edaspidi peab suhtuma allikakriitiliselt revisjonide kirjapilti ning arvestama kirjapanijate keelelist tausta ja keeleoskust. 1688. aasta revisjoni ajal koguti andmed juba nii mõisnike esitatud vakuraamatute põhjal kui ka inkvisitsiooni ehk küsitluse teel; nii oli see ka XVIII sajandil.

${ }^{8}$ Arusaadavalt pole $M u l k i$ nimega Lätis tegeldud nii intensiivselt kui Mulgi-nimedega Eestis. Kuramaalt on teada Mulki Dundagas ja Molcke Gipkas 1582./1583. aastal (Gipka oli liivlaste küla Kuramaa rannal) (Arbusow 1924: 219, 277; Endzelīns 1925: 145-146, 168; Blese 1929: 32, 299).

${ }^{9}$ Eeskätt hajatalu nimi võis püsida ka siis, kui elanikud vahetusid.

${ }^{10}$ Meile teadaolevates XVII sajandi materjalides sellist nimekuju ei esine.

${ }^{11}$ Mulcke-nimed esinevad nt ka Räpinas 1638 (Liivimaa 1638: 256), kuid neist kujunes XVIII sajandi lõpuks Mulgu. 1624 Mulcka 1638 Mulcke 1688 Mulcko 1738 Mulgo $1795 \mathrm{Mulgu}$ (Rev. 1624/1627, 1: 68; SRA Östersjöprovinsernas jordrevisionshandlingar, 36: 239-240; RGADA.274.1.201: 1082; RA, EAA.1865.2.70/2, 1 38p-39).

${ }^{12}$ Sepa ametit pidanud mees oli Mulcke perest või elas sellenimelises kohas. 
Vaba 2017: 536). Praegune uurimisseis ei võimalda aga omavahel põhjuslikult siduda Ruhja kihelkonna lätistumist ja Mulk/Mulki/Mulgi lisanime laialdast esinemust Eesti alal muul moel kui lähtudes tõestamata eeldusest, et nimi on tingimata läti algupära. Raske on hinnata, kui „soodsad” olid olud mikroetnonüümi mulk tekkeks sõjast, katkust ja näljast räsitud Liivimaa aladel, küll aga teame hästi, et „Villandimaa rahva” tulv ja edukas osturänne XIX sajandi keskpaigast alates andsid sõimunime leiutamiseks küllaga põhjust tartumaalastele (Pae, Lust 2017). Eesti ala tollase nimevaraga on üldistavalt tegelenud mitu uurijat, kes on võrrelnud XVI sajandi lõpu ja XVII sajandi alguse revisjone. Kogu Lõuna-Eestis moodustasid XVI sajandi lõpul lühikesed, 2-3-silbilised, esmapilgul sageli arusaamatu tähenduse ja päritoluga nimed koos äratuntavalt eesnimeliste lisanimedega enamiku kõigist lisanimedest. Kõige lõunapoolsemas osas (sh Helmes) paistavad eriti silma 2-3-silbilised, harva pikemad vanapärased (vanaeesti eesnimedest või määramata päritoluga) lisanimed (Troska 1995: 56-57). Heldur Palli kinnitusel esines Helme ja Tarvastu piirkonna XVI sajandi lõpu nimevaras arvukalt muistse päritoluga eesti nimesid (Palli 1961b). Tõsiselt ja üksikasjalikult tollast rahvaste rännet (sh Eestisisest) uuritud pole. Rohkem teame vaid soomlaste kohta (Vasar 1931). Loodi mõisast hiljem eraldatud Pahuvere mõisa all 1624. aastal elanud Mulck Jan oli tulnud 20 aasta eest Karksist ${ }^{13}$ (Rev. 1624, 2: 63) ja 1624. aastal Veeliksele asunud Mulggi Hann ( Mullgi Han) pärines Abjast (Rev. 1638: 69, 79, 123, 131; Rev. 1624, 2: 64). ${ }^{14}$ Hann (vt ka eel- ja allpool koos Mulgi-nimedega) on nii vanaeesti (ja liivi) nimi kui ka lühend Johannesest (Palli 1961b: 109, 124). Abja mõisa lisanimede analüüs 1624., 1638. ja 1688. aasta revisjoni põhjal ei anna tunnistust selle nimevara lätistumisest. ${ }^{15}$

Me teame üsna vähe lisanimede liikumisest ja püsimisest ning kinnistumisest kindlatele taludele. Nimede püsivus (suurtes) väljakülades oli tunduvalt väiksem kui metsakülades või hajataludes. XVI sajandi lõpul polnud peredel ega taludel kindlaid põlvest põlve kanduvaid nimesid (Troska 1995: 37). XVII sajandi algupoolel tulid Lõuna-Eestis käibele uued lisanimed. Harva võis leida lisanimesid, mida samas külas või mõisapiirkonnas oli kandnud mõni eelmine peremees XVI sajandi lõpul. Nimede järjepidevus katkes sealgi, kus kohalik rahvastik rasked ajad üle elas. Eelöeldu aga ei tähenda, et lisanimede andmise põhimõtted või nende üldine laad oleksid XVII sajandil muutunud (Troska 1995: 37-38, 56-57). Lisanime kasutamine ühel ja samal perekonnal läbi aastakümnete või kauemgi muutub paremini jälgitavaks meetrikate põhjal, mida on rohkem säilinud alates XVIII sajandist. XVII ja XVIII sajandil oli lisanimi Mulk : Mulgi levinud ka piirkondades, kus nimesaamine lätlastelt ei leia kinnitust.

Vaba väidab, et pole „mõeldav” kaasata lisanime Mulli(ka) sõnade ringi, millest Mulgi-nimed tuletuvad (Vaba 2017: 538). Tegelikult näitavad asustus- ja rahvastikuloolised allikad muud. Emakeele Seltsi koosolekul 8. mail 1920. aastal esitas Karp Tiisik teooria, et nimetus mulk tuletub sõnast mullikas, lisades küll samas, et mullikas tähendab täissöönud meest (ESA 1921: 9). Lisanimi Mulk : Mulgi (ja mitte vahetult mikroetnonüüm mulk) on mitmel pool kujunenud lisanimest $\operatorname{Mullik}(a)$ või vaheldunud sellise lisanimega. Hel-

\footnotetext{
${ }^{13}$ Karksi oli nii mõis kui ka linnuselään, mille alla kuulus ka Abja mõis.

${ }^{14} \mathrm{Nii}$ ei peaks olema võimatu nime siire ka Abjast lõuna suunas.

${ }^{15}$ 1689. aasta vakuraamatus on mõned sellised nimed (Kauli, Kalpa jt).
} 
mes 1599 Mulik 1638 Mulcky (ZD 24: 247; Rev. 1638: 123);16 Eense külas 1618 Mullicka Simon 1624 Mulck Simon (SRA Baltiska fogderäkenskaper f 390: 29, 55; Rev. 1624, 2: 26); Kastnas 1779 Mullika 1786, 1787 Mulki (RA, EAA.1283.2.1); ${ }^{17}$ Udrikul 1725/1726 Mullick Jürri 1732 Mulk Jürrj. Keskkülas (vt eespool), Hüürul ja Tarvastus on neid lisanimesid eri allikates samaaegselt või vahelduvalt kasutatud sõltuvalt kirjapanija arusaamisest või suvast. Hüüru Lehmja külas 1688 Mullika Mulcke Mart; ${ }^{18} 1699$ Mulcka ja Mulcki; 1743 Mulgi, 1744 Mulcke 1766 Mulki (RA, EAA.1.2.940, 1 879p-881p; EAA.1.2.943; EAA.3.1.479; EAA.1214.2.5; EAA.1214.2.6). Tarvastu mõisa Väluste külas asub Nenne Anders Kort'i kohale 1706 Muluk Adam 1722 Mulka Adam 1738 Mulki Adam 1744 Molluck Adam 1747 Mullick Adam 1751 Mulki Adam 1760 Mulgi Ado ${ }^{19}$ (RA, EAA.567.3.121; EAA.567.3.122; RGADA.274.1.202; RGADA.274.1.214). ${ }^{20}$ Mõlemad nimed esinevad samas külas ning ilmselt tähistasid ka sama pere või talu Lästes (1732 Mullica, 1782 Mulki (RA, EAA.1864.2.IV-6:374)) ja Pühastes (1624 Molloka Tinno, 1638 Mollack Tinno ;1 1688 Mulcky Hann, 1712 ja järgnevatel aastatel Mulgi (Rev. 1624/27, 1: 150; Liivimaa 1638: 98; SRA Östersjöprovinsernas jordrevisionshandlingar, 38; RA, EAA.1264.2.4).

Lisanime Mullikas kohtab ka varauusaegses linnakeskkonnas. Tallinnas oli pikka aega kraamipoe üürnik eestlane Hans (ka Ihan, Jan, Jahn) Mullikas (Mullekaß Mollekaß Mullekas Mullikaß Muhlkas), kes esineb vähemalt aastail 1582-1604 (Kala 2017: 76-77).

\section{Mulgi- ja Mullik-nimede tõlgendusi}

Mulgi-lisanimede, hilisemate talunimede kirjapildile on iseloomulik, et palju esineb variante, kus $l$-i ja klusiili $(k, g)$ vahel on vokaal. Kas see vokaal on kadunud loomuliku hilise sisekao teel või on tegemist nimedes vahel esineva ebareeglipärase lühenemisega? Teise silbi vokaali kadumine helitute konsonantide või helilise ja helitu konsonandi vahel, nt hal'tet 'hallitanud', haltas 'halutab ehk valutab', joot' $k$ 'joodik', koptamine 'koputamine', tän'ttänüq 'tänitanud', kohanimed Ad'stõ - Adiste ja Niits'ko - Niitsiku, on eriti iseloomulik idavõru ja Setu murrakutele ning Tartu murdeala idaosale (Keem, Käsi 2002: 35). Selles piirkonnas vanu Mulgi-talunimesid ei esine. Loomulikku sisekadu ei saa oletada ka selle tõttu, et kadunud vokaali peaks kompenseerima vähemasti kolmas välde: *mul'ki.

Mitmed nimenäited jätavad mulje, et tegemist on $k$-d mitte tüve osana, vaid sufiksi *-kko või *-kka jäänukina sisaldavate nimedega. Raske on mõista, miks sellisel juhul lõpevad hilisemad nimevariandid sageli $i$-ga, mitte - $u$ või $a$-ga.

\footnotetext{
${ }^{16}$ Janemeckulas/Jennamestekuell'is.

${ }^{17}$ Tegemist on Peteriga, kes oli abielus Mariga. Nimed pärinevad sünnimeetrikast.

${ }_{18}$ Tegemist on sama isikuga (peremees Mart), kelle nimi on samal aastal rts $\mathrm{k}$ vakuraamatus Mullika ja sks k Mulcke.

${ }_{19}$ Talusse tulnud uut peremeest nimetati mõnda aega ka vana, 1688. aastal elanud peremehe lisanimega, kuni uue peremehe nimi sai lõpuks talunimeks (Troska 1995: 35).

${ }^{20}$ 1586. ja 1599. aastal (talukoht tühi) on Tarvastu mõisa Järveküla all Mulika Peter (Poln. Akten IV: 220; ZD 24: 23). Väluste külas 1688 Mulcky Mulcke (SRA Östersjöprovinsernas jordrevisionshandlingar, 38).

${ }^{21}$ Esisilbi o-ga nimekujud panevad võrdlema murdesõnadega moolukas, mulgas, mullikas, muulik, molohk tähenduses 'muulukas' või 'murakas'.
} 
Kokkuvõttes on usutavam võimalus, et Mullika ja Mulgi on olnud rööpsed, erinevalt realiseerunud nimekujud samast sõnatüvest ja sama nimetekke motiivi põhjal, aga mitte et Mulgi oleks Mullika'st lühenenud. Erinevate nimekujude liiga väike ajaline distants ei lubagi sellist lühenemist kuigi usutavaks pidada.

Lisa- ja talunimede kirjapildis äratab tähelepanu varieerumise sarnasus sõna muulukas varieerumisega. Wiedemanni sõnaraamatu Jakob Hurda toimetatud versioonis on ühe märksõna alla ühendatud mūlukas, murkam, mullakas, mūlakas, molohk, mulikas, mulk, mūl', mülik, mülikas (Wiedemann 1973 [1893]: 636). Mõni marjanimetus on varauusaegse talupoja lisanimena küllalt levinud, eriti näiteks Maasikas Maasik Maask, aga muulukas on pigem näide sellest, kui erinevalt on realiseerunud üks lähedase kõlaga tuletiste pesakond. Meid huvitavate $M u l g i$-nimedega see ei sobi, sest pika $u$-ga variantidest, mis muuluka puhul domineerivad, pole Mulgi-nimede juures midagi teada.

Soome perekonnanime Mulli on Pirjo Mikkonen ja Sirkka Paikkala kokku viinud sõnaga mulli mullikka 'mullikas'. Lisanime XVI sajandi kirjapilte: Mulli, ${ }^{22}$ Mullicka, Mulicka (Mikkonen, Paikkala 1992: 336). Mullikas on sõna, mida etümoloogilistes sõnaraamatutes seotakse valdavalt noorlooma mullususega (SSA mulli; EES: 287 mullikas). Sõna on sarnane, kuid mitte sama päritolu soome sõnaga muli 'nudipea, sarvedeta veis' (SSA: muli). Et mulli(kka) on soome keeles tähendanud ka just härjavärssi, noort veohärga, siis on Mikkonen ja Paikkala pidanud üheks võimalikuks lisanime motiiviks härgadega silma paistvat peremeest, samamoodi nagu varauusaegsetes lisanimedes esinevad tihti sõnad sonni 'sõnn' ja härkä 'härg'. Teine võimalus on inimese võrdlemine mullika ehk härjavärsiga (Mikkonen, Paikkala 1992: 336).

Mullikka mullik mullikas on ilmselt läänemeresoome omasõna tuletis ja seda võidi kasutada ka otse inimese kohta mullususe või „muuga” seoses. Mullusus ja „muu” võis siin olla otsene - silmatorkavalt palju Mulk- ja Mullik-lisanime kandjaid ilmub revisjonides uustulnukatena ja/või on neil külast eraldi põlluala. ${ }^{23}$ Mullikuks või mullikaks nimetamist võib kujutleda ka metafoorselt, nii nagu naiivseid, pikaldase mõtlemise või vähese aruga inimesi on nimetatud eile sündinud, eilne, eeläne. Kuid kuna mullika sellist tähendust sõnavarakogudes registreeritud pole, ei saa seda rahuldava seletusena esitada. Mullika-nimeseletus jätab ka vastamata küsimusele, kuidas nimest võis tekkida Mulgi-variant.

Nendel juhtumitel, kus Soome allikates on Mulli selgelt ajalooline eesnimi, oleks seda õigem pidada hoopis Samueli muganduseks. Näiteks on Samueli muganduseks vana eesnimi ja nüüdne perekonnanimi Muilu (Mikkonen, Paikkala 1992: 335).

Eespool toodutest parem lahendus läänemeresoome nimevaraga seoses võiks olla säilinud soome ja karjala keele ühises sõnavaras. Karjala ametlikule venepärastatud perekonnanimele Mullijev (Муллиев) vastab karjalakeelne lisanimi Mulli. Isikunimede uurija Olga Karlova on seda võrrelnud karjala omadussõnaga mulliško 'mulkoilevasta, synkästä, jurosta ihmisestä tai härästä [põrnitseva, sünge, mossis inimese või härja kohta]'. Karjala keeles

${ }^{22}$ Mulli Keskkülas 1530. aastatel (Stackelberg 1928: 135). Mull(i)-lisanime kohtab XVI sajandi vakuraamatutes ja hilisemates maarevisjonides mitmel pool Eestis.

${ }^{23}$ Vt nt 1599. aastal mitmel pool Viljandimaal ka Mulli, Mulik(e), Mulikoss (ZS 24: 23, $200,207,247,285)$. 
on veel sõnad mul'tallah, mul'talleh 'silmistä muljallaan [silmad jõllis, silmi pööritav]', mul'l'asilmä 'mulkosilmä [punnsilm]' (Karlova 2016: 155). Vrd sm muljauttaa ning mulkaista 'jõllitada' ja mulkosilmä 'punnsilm, jõllsilm'. See sõnapesa pakub võimalust nii jõllitaja kohta loodud tuletisele nõrga astme tüvest: *mullikko, kui ka tüves $k$-d sisaldavaks variandiks: *mulko. Häälikuseaduslikult peaks olema eesti keeles mulg, teisalt soome sõnale malka vastab eesti keeles malk, mitte malg. Ka tüvevokaali asendumisele (- $a$ või -o asemele -i) võib mullik *mulgo (> mullik mulgi) variantide kõrvuti kasutamise puhul leida rahuldava seletuse.

On selge, et 'punnsilm' või 'jõllitaja' sobib hästi inimese individuaalseks lisanimeks, sellest saavad sündida just üksikud talunimed, mitte otseteed etnonüüm. Läänemeresoome-saami sõna (SSA: mulko) võis olla olnud tuntud veel ka varauusaegses Eestis. See, et Mulgi talusid ei tekkinud XVI-XVIII sajandil Võru- ja Tartumaal, võib olla seotud mulgu-sõna arenguga lõunaeesti keele tuumikalal: mulk : mulgu, mille algne tähendus oli 'aiaauk', hakkas seal tähendama auku igas mõttes. Hüpoteetiline *mul'ksilm 'punnsilm' ja XX sajandi keeles igapäevane mulkuvaonuq silmäq 'aukus silmad' oleksid lihtsalt täielikud semantilised vastandid.

Nimevariantide Mulk ja Mullik vaheldumine üksteisele ajaliselt lähedal seisvates kirjapanekutes meenutab ka vaheldusi saksa nimedes. Näiteks Henke ja Henneke on $k$-sufiksiga moodustatud hellitusnimed lühinimest Henn(e), mis võib olla nii Heinrichist kui Johannesest lähtunud (Kohlheim, Kohlheim 2008: 290). Samamoodi on Dietmarist lähtunud nimevariantide hulgas Timcke ja Timmeke. Ühe võimaliku võrdlusena võiks tuua saksa perekonnanime, kunagise lisanime Mull keskalamsaksa sõnast mül, mule 'suu, suuvärk, lõuad' (Kohlheim, Kohlheim 2008: 428).

Kuigi mõni eespool toodud seletuskatsetest sobib kirjapandud talunimedega paremini ja teine halvemini, ei saa neist ühtegi kindlaks ja põhimõtteliselt ainsaks talunimede allikaks lugeda. Nimedele ongi iseloomulik, et tähenduse hämardumine võib esile kutsuda kuju muutumise kasutajate suus. Teatud nimeandmispõhimõtted on universaalsemad, lisanime saaja välimust või iseloomu kirjeldav sõna on sageli algupärasem kui elukoha seostamine metsamarjadega või inimese seostamine mullikate ja härgadega, keda tema talus leidus. Peresid ja talusid tähistavate nimedena funktsioneerivad need kõik siiski ühtviisi hästi.

Ka läti mulk,is kõlbaks algupäraseks lisanimeks, sest üldiselt ei ole talupojakogukonnas tavaks olnud halvustavaid lisanimesid vältida, kuid samal ajal on „rumal” siiski liialt üldistava tähendusega sõna. Teoreetiliselt sobiks selline tähendus just teise etnose nimetamiseks; kogukonna sees leitakse lisanimedeks erilisemad markerid. Eestis on teada nöökivate või sõimunimedena näiteks Kaltz, Karroperse, Korositt, Sitt, Laisake, Kirkuwaraß, Korajalck, Kebberjalck, Layphe jt (Palli 1961a: 138; Põltsam-Jürjo 2011: 35).

\section{Kokkuvõtteks}

Max Vasmeri tõestusest mikroetnonüümi mulk lätilaenulisuse kohta ei ole leidnud kinnitust väide, et tegemist oli lounnaviljandimaalaste enesekohase nimetusega. Samuti ei tunne eesti murdesõnastikud Mandri-Eestis sõna mul'k 
tähenduses 'loll'. Sõna mulk rahvanimetuse tähenduses ilmub kirjakeeles käibele 1860.-1870. aastatel ja on seotud Lõuna-Viljandimaalt ja Pärnumaalt pärit talude päriseksostjatega Tartumaal. Kirjakultuuris on nn algmulke seotud Atika küla Mulgi taludest Tartumaale tulnutega.

Lisanime Mulk : Mulgi on esinenud eestlaste asualal vähemalt alates XVI sajandi keskpaigast. Mulgi-lisanimed varieeruvad allikates mitut puhku Mullikja Mullikas-tüüpi lisanimedega. XVII sajandi revisjonides leiab sõnale mulkis viitavaid lisanimesid Liivimaa Läti alal väga sporaadiliselt, ${ }^{24}$ samal ajal kui eestlaste asualal olid Mulk ja Mulki levinud mitmel pool üle Mandri-Eesti. Mullika ja Mulgi on olnud pigem rööpsed, erinevalt realiseerunud nimekujud samast sõnatüvest ja sama nimetekke motiivi põhjal ning ei saa väita, et Mulgi oleks Mullika'st lühenenud. Erinevatest tõlgendamisvõimalustest tõepäraseim näib, et mullikka mullik mullikas on läänemeresoome tuletis ja seda võidi kasutada ka otse inimese kohta mullususe või „muuga” seoses. Mullusus ja „muu” võis siin olla otsene: silmatorkavalt palju Mulk- ja Mullik-lisanime kandjaid ilmub revisjonides uustulnukatena ja/või on neil külast eraldi põlluala. Mullika-nimeseletus jätab aga vastamata küsimusele, kuidas nimest võis tekkida Mulgi-variant.

Erinevad tõlgendamisvõimalused ei pruugi üksteist välistada. On võimalik, et lõpuks välja kujunenud talunimed Mulgi, perekonnanimed Mulk, Mulkson jt omavad individuaalsete juhtumitena erinevat tausta - läänemeresoome-, saksa- või ka lätipärast. Ka XVI ja XVII sajandi lisanimede hulka võib kuuluda selliseid, mille aluseks on läti sõna, kuid täiesti ilmselt ei saa vanade Mulgi-nimede levimise põhiliseks lähtekohaks pidada Lätit ega läti keele kontaktala.

Artikkel on valminud uurimisprogrammide IUT2-17 „Rahvastiku ruumiline mobiilsus ja linnaregioonide areng” ja EKKM 14-376 „Kagu-Eesti vanad isikunimed" toel.

\section{Allikad}

Rahvusarhiiv (RA):

EAA.1 Eestimaa rootsiaegne kindralkuberner

EAA.3 Tallinna kindralkuberner

EAA.308 Liivimaa kubermangu joonestuskoda

EAA.567 Liivimaa maamõõdu revisjonikomisjon

EAA.1214 EELK Keila kogudus

EAA.1227 EELK Kadrina kogudus

EAA.1236 EELK Koeru kogudus

EAA.1242 EELK Kirbla kogudus

EAA.1264 EELK Rõngu kogudus

EAA.1275 EELK Halliste kogudus

EAA.1283 EELK Tõstamaa kogudus

EAA.1286 EELK Paistu kogudus

EAA.1288 EELK Tarvastu kogudus

EAA.1862 Perekond Stackelberg

${ }^{24}$ Järjepideva liini saaks konstrueerida vaid Ruhja mõisas. 
EAA.1864 Eestimaa kubermangu revisjonilehtede kollektsioon

EAA.1865 Liivimaa kubermangu revisjonilehtede kollektsioon

Tallinna Linnaarhiiv:

TLA.230 Tallinna magistraat

Läti Riiklik Ajalooarhiiv:

LVVA.7349 Liivimaa rootsiaegne kindralkuberner

Venemaa Vanade Aktide Riiklik Keskarhiiv:

RGADA.274 Liivi- ja Eestimaa ning Soome asjade kammerkontor

Rootsi Riigiarhiiv:

SRA Östersjöprovinsernas jordrevisionshandlingar

SRA Baltiska fogderäkenskaper

\section{Kirjandus}

Arbus ow, Leonid 1924. Ein Verzeichnis der bäuerlichen Abgaben im Stift Kurland (1582/83). - Acta Universitatis Latviensis. Latvias Universitātes Raksti. X. Rīga, lk 163-278.

Bles e, Ernests 1929. Latviešu personu vārda un uzvārda studijas. I. Riga.

Dunsdorfs, Edgars 1974. Der grosse schwedische Kataster in Livland 16811710. Kartenband. Melbourne.

EES = Eesti etümoloogiasõnaraamat. Peatoim Iris Metsmägi. Koost ja toim Iris Metsmägi, Meeli Sedrik, Sven-Erik Soosaar. Tallinn: Eesti Keele Sihtasutus, 2012.

EMS = Eesti murrete sõnaraamat. Kd 5, v 25. Maagudama-mehiläne. Toim MariLiis Kalvik, Mari Kendla, Tiina Laansalu. Tallinn: Eesti Keele Sihtasutus, 2015.

En d z elīn s, Jānis 1925. Latvijas vietu vārdi. II. Kurzemes un Latgales vārdi. Rīga. Endzelīns, Jānis 1961. Latvijas PSR vietvardi. I dala. 2. sejums, K-O. Rīga: Latvijas PSR Zinatnu Akademijas izdevnieciba.

ESA 1921 = Akadeemilise Emakeele Seltsi aastaraamat. I (1920). Tartu.

J o h a n s e n, Paul 1938. Bruchstücke des Landbuches der Ordensmeister für Rujen und Helmet. - Beiträge zur Kunde Estlands. Kd 21, v 1. Tallinn, lk 43-61.

Kala, Tiina 2017. Eesti keel pärisnimede ja etnonüümide näitel mõnedes varauusaegsetes Tallinna allikates. - Vana Tallinn, kd 28, nr 32, lk 57-82.

Karlova, Olga 2016. Omaperäisten henkilönnimien säilyminen lisänimissä ja sukunimissä (Savo, Karjala, Vepsä). - Õdagumeresuumlaisi nimeq. Läänemeresoomlaste nimed. (Võro Instituudi toimõndusõq 30.) Toim Jüvä Sullõv. Võro: Võro Instituut, lk 139-165.

Kar u lis, Konstantīns 2001. Latviešu etimoloǵijas vārdnīca. Rīga: Avots.

Ke e m, Hella, Käsi, Inge 2002. Võru murde tekstid. (Eesti murded VI.) Tallinn: Eesti Keele Instituut.

Kohlhei m, Rosa, Kohlh ei m, Volker 2008. Duden. Lexikon der Familiennamen. Herkunft und Bedeutung von 20000 Nachnamen. Mannheim-Zürich: Dudenverlag.

Körber, Carl 1866. Über das Wort „mulk”, pl. „mulgid”. - Õpetatud Eesti Seltsi aastaraamat. / Sitzungsberichte der Gelehrten Estnischen Gesellschaft zu Dorpat. Dorpat, lk 20.

LD = Latvju dainas, I. Krišjānis Barons, Henrijs Visendorfs. Jelgava, 1894. 
Liivimaa 1638. a. maarevisjon. Eesti asustusala. 1, kaguosa. (ENSV Riigi Keskarhiivi Tartu osakonna toimetused, kd 1, nr 7.) Tartu: Teaduslik Kirjandus, 1941.

Mikk on en, Pirjo, Paikka la, Sirkka 1992. Sukunimet. Toinen painos. Helsinki: Otava.

Pa e, Taavi, Lust, Kersti 2017. Mulkide nimetuse saamisloost ehk kas mulgid on tõesti rumalad. - Keel ja Kirjandus, nr 6, lk 434-452.

Palli, Heldur 1961a. Eesti isikunimede kasutamisest meie rahva vanema ajaloo (XIII-XVI saj.) uurimisel. - ENSV TA Toimetised. Ühiskonnateadused, kd 10, nr 2, lk 132-143.

Palli, Heldur 1961b. Mida kõnelevad isikunimed eestlaste usust XIII-XVI sajandil. - Religiooni ja ateismi ajaloost Eestis. Koost Ea Jansen. Tallinn: ERK, lk 108-127.

Poln. Akten = Polnische Akten IV. 1583-1590. Hefte zur Landeskunde Estlands. H. 6, Toim Oleg Roslavlev. München, 1973.

Põlt s a m - J ü rj o, Inna 2011. Sissevaateid Liivimaa külaühiskonda 15.-16. sajandil. - Tuna, nr 1, lk 20-41.

Rev. 1601 = Die Revision Livlands 1601. Estnisches Siedlungsgebiet. Hefte zur Landeskunde Estlands. Kd 3. Toim Oleg Roslavlev. München, 1967.

Rev. 1624, 1 = Das Dorpater Land. 1624/27. Hefte zur Landeskunde Estlands. Toim Oleg Roslavlev. Kd 1. München, 1965.

Rev. 1624, 2 = Das Pernauer Land 1624. Hefte zur Landeskunde Estlands. Kd 2. Toim Oleg Roslavlev. München, 1967.

Rev. 1638 = Die Revision Livlands 1638. Estnisches Siedlungsgebiet, 2. Hefte zur Landeskunde Estlands. Kd 4. Toim Oleg Roslavlev. München, 1969.

Rozenbergs, Jānis 2005. Tautas un zemes latviešu tautasdziesmās. Rīga: Zinātne.

S a a r e s te, Andrus 1935. Eesti liignimedest varemalt, nüüd ja tulevikus. Tallinn: Nimede eestistamise kesktoimkonna kirjastus.

SSA = Suomen sanojen alkuperä. Etymologinen sanakirja. I-III. (Suomalaisen Kirjallisuuden Seuran toimituksia 556. Kotimaisten kielten tutkimuskeskuksen julkasuja 62.) Helsinki 1992-2000.

St a ckelberg, Friedrich 1928. Das älteste Wackenbuch der Wiek (1518-1544). Õpetatud Eesti Seltsi aastaraamat. / Sitzungsberichte der Gelehrten Estnischen Gesellschaft 1927. Tartu: K. Mattiesen, lk 78-276.

Švābe, Arveds 1933. Die älteste schwedische Landrevision Livlands (1610). Akta Universitatis Latviensis. Latvijas Universitātes Raksti. Tautsaimniecības un tiesību zinātṇu fakultātes serija, kd 2, nr 3. Riga, lk 337-596.

ZD 24 = Źródła dziejowe, 24. Polska XVI wieku pod względem geograficznostatystycznym, 13. Toim Józef Jakubowski, Jan Kordzikowski. Warszawa: Gebethner i Wolff, 1915.

Tallinna turberaamat. 1515-1626. I osa. Tekst. / Das Revaler Geleitsbuch. 15151626. I Teil, Text. (Tallinna linnaarhiivi väljaanded. / Publikationen aus dem Stadtarchiv Tallinn 9.) Toim Nikolai Essen, Paul Johansen. Tallinn, 1939.

Tr o sk a, Gea 1995. Talunimed läbi aegade. Tallinn: Teaduste Akadeemia Kirjastus. V a ba, Lembit 1997. Uurimusi läti-eesti keelesuhetest. Tallinn-Tampere: Eesti Keele Instituut, Tampereen Yliopiston suomen kielen ja yleisen kielitieteen laitos.

V a b a, Lembit 2017. Rumalad mulgid ehk etümologiseerimise okkaline tee. - Keel ja Kirjandus, nr 7, lk 534-540. 
Vanem Tallinna Jaani haigemaja vakuraamat. / Das älteste Wackenbuch des Revaler St. Johannis-Siechenhauses. 1435-1507. (Tallinna linna arhiivi väljaanded. / Publikationen aus dem Revaler Stadtarchiv, kd 2, v 4.) Toim Paul Johansen. Tallinn: Eestimaa Trükikoja Aktsia-Selts, 1925.

V a s a r, Juhan 1931. Soome asustusest Eestis XVII sajandi keskel. - Eesti Kirjandus, nr 11, lk 549-567; nr 12, lk 639-652.

V a s m e r, Max 1920. Indo-Germaani laensõnad Eesti keeles. - Eesti Kirjandus, nr 11-12, lk 343-346.

Vidzemes 1638. gada arklu revizija. Latviešu novadi. Actus revisionis Livonoae 1638. Pars Latvie. Die Hakenrevision Livlands 1638. Lettischer Teil. Kd 3: Vecsalace, Rūjene, Ērógeme, Lugaži, Alūksne, Gulbene, Gaujiena, Koknese, Bērzaune, Cesvaine, Suntaži, Zaube, Ērgḷi, Skujene, Piebalga un Madliena. Toim Edgars Dunsdorfs. Riga: Latvijas vēstures institūts, 1941.

Vogelsang, Reinhard 1976. Kämmereibuch der Stadt Reval 1432-1463. (Quellen und Darstellungen zur hansischen Geschichte N. F., kd 22, v 2.) Köln-Wien: Böhlau.

Wi ed e m a n n, Ferdinand Johann 1973 [1893]. Eesti-saksa sõnaraamat. Neljas, muutmata trükk teisest, Jakob Hurda redigeeritud väljaandest. Tallinn: Valgus.

\section{Once again about the „foolish Mulks”}

Keywords: etymology of bynames, place names and folk names

The article challenges again the widespread belief that the folk name Mulks derives from the Latvian word mulkis, mulke 'stupid, fool'. The article explores in detail the spread of the byname Mulk and Mulgi in its various forms in early modern Estland, Livland and Kurland and comes to the conclusion that it was strikingly more common in Estonian-speaking areas than in the Latvian-speaking ones. In principle, the word mulkis could fit as a byname, but village dwellers generally preferred more specific words to designate other community members. The byname and place name Mulgi in the Estonian-speaking areas does not have to have one single root but in different cases it can originate either from Balto-Finnic, German or Latvian languages. In two cases Finns had this byname. Land revision materials and church books indicate that in several places all over Estonia the byname Mulgi is related to an earlier or parallel name Mulli(ka) (Fin mulli mullikka 'steer'). We suppose that this relationship between Mulli(ka) and Mulgi cannot be explained by irregular shortening of the word $M u l l i(k a)$ but they both derive from the same stem. The varying of Mulk and Mullik close in time resembles the variation of the names Henke/Henneke and Timcke/Timmeke in German.

Kersti Lust (b. 1976), PhD, University of Tallinn, Estonian Institute for Population Studies, Senior Research Fellow in Historical Demography, kersti_lust@yahoo.com

Taavi Pae (b. 1976), PhD, University of Tartu, Department of Geography, Research Fellow in Human Geography, taavi.pae@ut.ee

Evar Saar (b. 1969), PhD, Võru Institute, ResearchFellow,evar.saar@wi.ee 